Fordham University

Fordham Research Commons

\title{
Shift Work, Father Engagement, and the Cognitive Development of Young Children
}

\author{
Matthew Weinshenker \\ weinshenker@fordham.edu
}

Follow this and additional works at: https://research.library.fordham.edu/soc_facultypubs

Part of the Child Psychology Commons, Developmental Psychology Commons, Family, Life Course, and Society Commons, and the Work, Economy and Organizations Commons

\section{Recommended Citation}

Weinshenker, Matthew, "Shift Work, Father Engagement, and the Cognitive Development of Young Children" (2018). Sociology Faculty Publications. 19.

https://research.library.fordham.edu/soc_facultypubs/19

This Article is brought to you for free and open access by the Sociology at Fordham Research Commons. It has been accepted for inclusion in Sociology Faculty Publications by an authorized administrator of Fordham Research Commons. For more information, please contact considine@fordham.edu, bkilee@fordham.edu. 


\section{Shift Work, Father Engagement, and the Cognitive Development of Young Children}

Matthew Weinshenker

Department of Sociology \& Anthropology, Fordham University, Bronx, NY, USA

Address correspondence to: Matthew Weinshenker, Department of Sociology \& Anthropology, Fordham University, 441 East Fordham Road, Bronx, NY 10458, USA. Telephone: (718) 8170724. Fax: (718) 817-3846. Email: weinshenker@ fordham.edu.

This article was published in Community, Work \& Family, 21:2 133-150, DOI:

10.1080/13668803.2018.1428171. The final publication is available at https://www.tandfonline.com/doi/full/10.1080/13668803.2018.1428171. 


\begin{abstract}
The present study investigates whether the effect of fathers' positive engagement on young children's cognitive development is accentuated when one or both dual-earner parents is employed during non-standard hours. Longitudinal regression models are fitted to three waves of nationally-representative data from the Early Child Longitudinal Study-Birth Cohort. Father engagement when children are nine months old has an especially positive effect on children's cognitive ability at age two when the father works during the day and the mother has a fixed evening or night shift. There are no interactions between shift work and engagement at age two in the whole sample, but subgroup analyses show that engagement has an especially strong effect on children who have a non-parent caregiver if both parents are shift workers. The results highlight the important role fathers play in couples with a shift worker, and provide a rationale for efforts to encourage and support their involvement.
\end{abstract}

Keywords: development, dual-earner, fathers, maternal employment, parental investment/involvement, paternal employment 
In recent years, the U.S. economy has increasingly shifted to a " $24 / 7$ " basis. In an influential book, Presser (2003) identified a variety of changes in the economy, in demographics, and in technology that have increased demand for work in the evenings, nights, and rotating shifts that change on a regular basis. In 2010, according to data provided by the National Center for Health Statistics, $28.6 \%$ of jobs required such a non-standard schedule (Alterman, Luckhaupt, Dahlhamer, Ward, \& Calvert, 2013). This is a cause for concern for the children of shift workers. Empirically, a small but fairly consistent literature has shown that shift work is a risk factor for poor child outcomes, including cognitive development (Han, 2005; Han \& Fox, 2011; Heyman, 2000; Odom, Vernon-Feagans, \& Crouter, 2013).

Given the prevalence of shift work, it is important to know as much as possible about ways to promote healthy development and well-being among shift workers' children. This investigation begins with the insight that, among dual-earner parents who are married or cohabiting, shift work frequently results in partially or completely non-overlapping employment schedules, with the father at home when the mother is on the job, and vice versa (Presser, 2003). I use nationally-representative panel data to examine whether fathers' positive engagement with young children makes a difference. Does it have an especially important effect on cognitive outcomes when men or their partners have non-standard hours?

Although appropriate father involvement is known to be valuable in general (Pleck, 2010), a finding that fathers have an especially important role to play when dual-earner couples work at different times of day would be of great interest to the large number of parents in this situation. It would also be valuable knowledge for professionals who work with fathers and families. 


\section{Background}

This study is framed in terms of the ecological approach to human development, which calls attention to the way that multiple, interlocking social systems affect children. Relationships with significant figures in a child's life - interactional microsystems - have the most immediate influences on development (Bronfenbrenner, 1994). These microsystems are shaped by social settings in which events influence the child even though he or she does not participate in them (the exosystem). Because events at work can "spill over" to affect parents' mood and behavior in the home in both positive and negative ways, the parental workplace is an important element of the exosystem (Bellavia \& Frone, 2004).

Although spillover from work to home may be either beneficial or harmful to workers and their families, the empirical literature has most often demonstrated negative outcomes. For workers themselves, non-standard schedules can interfere with sleep (Kalil, Dunifon, Crosby, \& Su, 2014), heighten feelings of work-family conflict, (Davis, Goodman, Pirretti, \& Almeida, 2008; Tammelin, Malinen, Rönkä, \& Verhoef, 2017), increase martial conflict and the perception of marital instability (Kalil, Ziol-Guest, \& Epstein, 2010; Perry-Jenkins, Goldberg, Pierce, \& Sayer, 2007; Strazdins, Clements, Korda, Broom, \& D'Souza, 2006), and increase the risk of depression (Perry-Jenkins et al., 2007; Strazdins et al., 2006). It can also reduce the sensitivity of parent-child interactions, reduce parent-child relationship quality, and interfere with the overall quality of the home environment (Davis, Crouter, \& McHale, 2006; Grzywacz, Daniel, Tucker, Walls, \& Leerkes, 2011; Lleras, 2008; Strazdins et al., 2006).

In turn, all of these outcomes are pathways by which shift work operates to place children's well-being at risk (Li et al., 2014). The most well-established finding is that shift work is a risk factor for children's behavioral development (e.g., Daniel, Grzywacz, Leerkes, Tucker, \& Han, 2009; Joshi \& Bogen, 2007; Rosenbaum \& Morett, 2009; Strazdins et al., 2006), 
although some studies have disagreed (Dunifon, Kalil, \& Bajracharya, 2005; Ross Phillips, 2002). A smaller literature has addressed cognitive development. Han (2005) found maternal nonstandard hours to have a negative effect on young children's cognitive test scores, especially if the mother began working a nonstandard schedule before the child's first birthday. A few other studies have also demonstrated harmful effects of parental shift work on children's cognitive scores (Han \& Fox, 2011; Heyman, 2000; Odom et al., 2013). However, Baker (2016) found that Black and Hispanic fathers' nonstandard employment was predictive of high subsequent reading scores in young children. It is significant that Baker's study is the only one to focus upon fathers specifically. Although its emphasis differed, Baker's article shared this study's focus on the relatively under-researched role of fathers in explaining the well-being of children of shift workers.

Specifically, the present study evaluates fathers' positive engagement as a moderator of the relationship between shift work and children's cognitive development in dual-earner families. Following Pleck, positive engagement is here defined as "interaction with the child of the more intensive kind likely to promote development" (Pleck, 2010, p. 61). Extensive research in the past few decades has convincingly demonstrated the value of positive engagement for children's well-being, including cognitive and academic outcomes (e.g. Duursma, 2014; Martin, Ryan, \& Brooks-Gunn, 2007; Tamis-LeMonda, Baumwell, \& Cabrera, 2013).

To the extent that shift work puts children's well-being at risk, either parent's positive engagement could ameliorate the situation. This study focuses on fathers because, in spite of a long-term trend towards greater involvement, U.S. fathers typically spend considerably less time with their children than mothers do (Pleck, 2010). Non-overlapping employment hours, however, tend to create a situation in which fathers are home and available to their young 
children when their partners are not. The principle of time availability (Coverman, 1983) leads to the prediction that such fathers will be more involved than average in a variety of forms of parenting. Yet empirical investigation only partly confirms this hypothesis. Researchers have found that fathers in couples with a shift worker do provide a large amount of care for young children. On the other hand, they are not more engaged in stimulating activities than other fathers in dual-earner families (Weinshenker, 2016; Wight, Raley, \& Bianchi, 2008).

In this study, the aim is to look beyond the average impact (or, rather, non-impact) of shift work on positive engagement. The question is: among the subset of fathers in dual-earner couples who are highly engaged when they or their partners work non-standard hours, does their parenting have an especially large protective effect on their young children's cognitive development? In other words, a possible interaction between shift work and positive engagement will be tested. To the best of my knowledge, the present study is the first to investigate this hypothesis.

Careful attention will be paid to two important contextual elements. First, some studies have found regular evening and night shifts to be more predictive of poor child outcomes, such as adolescent depression and low parent-child interaction, than rotating and other variable shifts (Han \& Miller, 2009; Rapoport \& Le Bourdais, 2008). This may be because some workers with variable shifts possess the flexibility to select their own schedules in a way that facilitates their parental responsibilities. This has been documented among relatively high-status shift workers such as nurses (Clawson \& Gerstel, 2014). Accordingly, the expectation is that father engagement can have a greater positive effect when he or his partner has a fixed nonstandard shift. 
Second, it is important to distinguish whether families make use of non-parental caregivers. Extra-familial care providers can engage in positive developmental behaviors just as parents can. Therefore, one might expect the impact of father engagement to be smaller when children spend time in outside care. On the other hand, non-parental care, with the possible exception of care by relatives, is primarily available during daytime hours. In the situation where one parent works during the day and the other works at night, the use of non-parental care will tend to mean the child spends relatively more time with the parent who works during the day, thereby heightening the importance of his or her parenting. Father engagement may be especially impactful when men work during the day and their partners are shift workers.

In this investigation, care will be taken to control for confounding factors. First and foremost, this includes maternal engagement. To the extent that parents exhibit similarity of behavior towards their children, failing to control for mothers' engagement threatens to overstate the impact of fathers' engagement. Next, as recommended by Li and co-authors (2014), I control for as many common sources of selection into nonstandard work as possible, including family socioeconomic status, receipt of public support, each parent's hours of employment, the father's age and race, the parents' marital status, and the number of children in the home. In addition, factors known to predict children's cognitive scores are included in the models, including the child's gender and age, whether the child has special needs, whether the child had a low birth weight, the number of books in child's environment, and average hours the child spends watching TV and movies. 


\section{Method}

\section{Data Source}

The analysis utilizes restricted-use data from the first three waves of the Early Child Longitudinal Study-Birth Cohort (ECLS-B), a nationally-representative sample of all children born in the U.S. in 2001 (nces.ed.gov/ecls/Birth.asp). ECLS-B, which has been conducted by the U.S. Department of Education's National Center for Education Statistics (NCES), was designed to facilitate longitudinal studies of children's early development and school readiness. The first data collection occurred at nine months, and it was followed by additional rounds at about 24 months and four years of age (the "preschool" observation). The major components of this multi-method, multiple-respondent data collection effort that are used here include computerassisted personal interviews with the child's primary parent (usually the mother), short selfadministered surveys filled out by a second caregiver (usually the father) if one is present, direct assessments of children's cognitive development. A very small amount of data was also taken from the survey of child care providers than was conducted at the 24 month observation. (For a full description of the data, see Snow et al., 2007.)

In this longitudinal study, parent engagement, work schedules, and various covariates are modeled as predictors of children's cognitive development at the subsequent observation. To disentangle the impact of shift work from that of disruption in family structure between observations, the sample is restricted to families in which the target child lives with the same two, opposite-sex, biological or adoptive parents at consecutive interviews. This means there are two samples with slightly different compositions: 2450 families where the predictors were measured when the child was nine months old and children's cognitive development was assessed at 24 months, and 2200 families where 24-month predictors are used to predict 
cognitive development at age four. (In keeping with NCES' confidentiality requirements, all sample sizes are rounded to the nearest 50.)

To get to these sample sizes from the original ECLS-B sample of 10,700 families, a number of additional restrictions were applied. Families were excluded in case of attrition from the survey, or if there was no second parent survey completed. (The weights that are applied to both the descriptive and regression results adjust for these sources of non-response.) Cases were also excluded if the respondent to the primary parent questionnaire was not the child's mother, or if the second parent respondent was not the father, because in either case crucial information about parental engagement was not measured. Finally, to simplify the results, families were only included if both parents were employed at the time the predictors were measured. (They need not have remained a dual-earner couple at the subsequent observation.) The key findings of the study were very similar when two-parent families with a single earner and with no earners were included.

\section{Cognitive Scores}

At the nine and 24-month observations, children's cognitive development was measured by means of the Bayley Short Form-Research edition (BSF-R) mental scale, which is a subset of the standardized Bayley Scales of Infant Development. Administered by trained interviewers in the child's home, these scores measure children's performance on a variety of developmentally appropriate tasks. For example, some of the tasks asked of nine-month-olds included "putting blocks in a cup, ringing a bell, and responding to a parent's request (e.g., peek-a-boo)" (Nord et al., 2004, p. 2-6). At 24 months, tasks included "naming pictures, verbal comprehension, discriminating objects and pictures, comparing sizes, and matching colors" among others (Nord et al., 2006, p. 2-6). 
To measure cognitive ability at age four, the ECLS-B researchers constructed an original instrument called the Early Reading and Math Assessment. The researchers conducted a field test of selected items from a number of existing instruments, including "the Peabody Picture Vocabulary Test (PPVT, various forms), the Preschool Comprehensive Test of Phonological and Print Processing (Pre-CTOPPP), the PreLAS® 2000, and the Test of Early Mathematics Ability3 (TEMA-3)" (Snow et al., 2007, p. 23). Additional items were taken from several earlier Department of Education assessments. After the field test, psychometric procedures were used to select the items in the final instrument.

The Early Reading and Math Assessment actually consists of several components: language, literacy, math, and color knowledge. (The color knowledge measure is not used in the present study.) The literacy assessment displayed a floor effect in the sample whereby 10 percent of children who took the English-language version scored worse than chance, indicating that the assessment could not discriminate among the lowest levels of literacy (Snow et al., 2007). This flaw in the measure should be kept in mind as a study limitation.

For the present analyses, the point of departure was two cognitive scores: the math score, and a reading score that combines language and literacy into one. But because of their very high correlation of .78 , the reading and math scores have been further aggregated into a single cognitive development measure. A log-10 transformation has been applied to make the combined score resemble a normal distribution.

\section{Positive Engagement}

Fathers' positive engagement is an index created by combining responses to seven questions about how frequently men reported in engaging in a number of cognitively stimulating activities and types of play. Questions about reading, singing, and telling stories were asked at both nine 
and 24 months. Responses originally ranged from 1 (not at all) to 4 (every day), but they were recoded from 1 to 6 for consistency with the other items. In these other questions, fathers of nine-month-olds reported on how frequently they play peek-a-boo, hold the child, stimulate him or her in several ways (such as tickling), and take the child outside. At 24 months, they reported on playing chasing games, giving the child a ride on the shoulders or back, playing indoors, and taking the child outside. These items were originally scored from 1 (more than once a day) to 6 (not at all), but were reverse-coded so that a high score on the index indicates greater engagement. In the analysis sample, the Cronbach's alpha coefficient is .65 for nine-month engagement and .74 at the 24-month observation.

Mothers also answered questions about engagement, although they differed in two respects from the father questions. For the play items, mothers were not asked about holding the child at nine months, nor about giving the child a shoulder or back ride at 24 months. More important, for the questions about reading, singing, and telling stories, mothers were asked how frequently anyone in the household did these things, not how often the mothers themselves did so. (The age-varying questions, by contrast, asked what mothers themselves did.) Mothers' reports about all family members were modestly correlated with fathers' self-reports; Pearson's r was about .30 for data collected at both nine and 24 months. Because of the minimal risk of multicollinearity, I decided to combine all the mother reports into a single index of maternal and family engagement, despite its somewhat ambiguous meaning. Cronbach's alpha is .58 at nine months and .59 at 24 months.

\section{Employment Schedules}

Parents' joint employment schedule is derived by cross-classifying mothers' reports of their own and their spouses' or partners' usual hours. In each survey wave, mothers were asked if they and 
their partner were employed, and if so, whether each usually worked a day, evening, night, rotating, split, or other kind of shift. Because of small cell sizes, fixed evening and night shifts were combined into one category, and all other nonstandard schedules (which were predominantly rotating and unspecified "other" schedules) were combined into a second group. This resulted in six categories of dual-earner couples:

(1) both parents work during the day (the reference group in all regression models);

(2) father day plus mother evening/night;

(3) father evening/night plus mother day;

(4) father day plus mother other nonstandard;

(5) father other nonstandard plus mother day;

(6) both parents work nonstandard shifts.

\section{Covariates}

Several covariates are included in the models to control for aspects of the parents' employment and financial situation. First, family socioeconomic status (SES) was measured in quintiles in the ECLS-B data. For this study, indicators were created for quintile membership; the lowest is the reference category. To measure the impact of work hours, indicators for part-time work (less than 35 hours per week) and for long hours (more than 45 per week) are controlled. Public income support is operationalized as an indicator of whether the family has received Temporary Assistance to Needy Families, Food Stamps (SNAP), or Medicaid since the child's birth (at the nine-month observation) or since the previous interview (when children are 24 months).

Covariates about the parents and the household begin with the father's age in years. The father's race is operationalized as four dummy variables, with non-Hispanic white omitted. The parents' marital status and the number of other children in the household are also included. 
The final set of covariates concerns the target child. First, a set of indicators is used to control for the number of hours the child spends in non-parental care. There are separate indicators for children who spend a low (1-40) or a high (more than 40) number of hours per week in non-parental care. There are also indicators for whether the child's primary care arrangement is in a child care center or an informal setting, such as care by a relative or a nanny in the home. For both sets of indicators, children who are only cared for by their parents are the omitted group.

Additional child measures include gender and age in months. Mothers also reported whether the child has any special needs on an extensive list that varied from interview to interview. In this study, an indicator has been set equal to one if mothers reported any special need aside from allergies. There is also an indicator of whether the child had a low birth weight.

Finally, at 24 months, mothers reported on how many books are in the home and on how many hours the child watches TV and movies per weekday; day care providers reported the same. The responses to the questions about books were averaged (for children in care) to create a measures of each child's literacy environment; when day care information is not provided, only the home measure is used. Similarly, the mother and caregiver responses (when applicable) about TV and movies were summed to create a measure of total viewing time on weekdays. The latter measure has been top-coded at 12 hours to reduce the influence of a small number of outliers. Both variables are included in models predicting cognitive scores among four-yearolds.

\section{Analysis Plan}

The findings presented in this paper are the results of nested OLS regression models produced in Stata 13.1. The models are longitudinal, with predictors drawn from one point in time, and 
children's cognitive scores from the subsequent observation. In the first model for each wave of data, children's cognitive scores are regressed on dual-earner parents' shifts and on the measures of father and mother engagement. The second model adds all the covariates described above, as well as a prior measure of cognitive development (concurrent with the predictors), which helps disentangle the effects of shift work and father involvement from children's baseline abilities (Johnson, 2005). The third model adds interactions between father engagement and parents' shifts, thereby testing the study's central hypothesis that fathers' involvement affects children's cognitive development more in families with a shift worker.

In a fourth model, I add concurrent measures of work schedules and each parent's engagement. In other words, work schedules and engagement measured at the same observation as the outcome are controlled in the model. These concurrent controls permit better specification of the longitudinal effects of prior work schedules and parental engagement, which are the study's main focus. Finally, separate versions of this fourth model are presented for families who do and do not have an outside care provider for their child.

All results are population weighted using the best available weight adjustment provided by NCES. To handle cases with partially missing data, ten imputed data sets were created using the ICE add-on for Stata (Royston, 2004). A combination of Stata's SVY commands and the MIM add-on was used to appropriately adjust the standard errors for both the complex survey design and the presence of imputed values. The models were also run on cases with complete data, and the results (not shown) were very similar to those presented here. 


\section{Results}

\section{Descriptive Statistics}

Descriptive statistics for the predictor variables in this study are presented by survey wave in Table 1. For the sake of brevity, only the most pertinent results will be discussed. First, in terms of prior employment schedules (measured at the baseline observation), both partners work during the day a majority of dual-earner couples when their children are nine and 24 months old. Those with a shift worker are widely distributed across the five types defined for this study. Although each group of couples with a shift worker is a modest percentage of the total sample, the smallest unweighted cell size is larger than 80 cases.

Turning to concurrent employment schedules (measured at the same time as the outcome), it remains true that both partners work during the day in most dual-earner homes. Although couples were included if they switched to a single or no-earner arrangement between observations, only a modest percentage had done so, reflecting a tendency toward persistence in dual-earner status. This is one of several results in Table 1 that reflect the nature of the sample and the study. To take another example, restricting the sample to dual-earner families at the baseline observation results in a small percentage of couples in the lowest SES quartile. Several other measures, such as the number of children in the household, change in ways consistent with a fifteen-month gap between observations.

Between the nine and 24-month observations, the average father engagement score declines somewhat. Mothers' reports of their own and their families' engagement do not. This supports the assumption that the mother measure is not heavily influenced by mothers' perceptions of their partners' engagement. However, both measures of engagement decline between the 24 month and the age four observations. 
One additional finding worthy of note is that, even though this is a dual-earner sample, about one-quarter of families report no usage of non-parental care at each baseline. In the data, these are disproportionately likely to be families with a shift worker, as will be discussed further below.

\section{Employment Schedules by Engagement}

Before testing the hypothesis that father engagement has a heightened effect on children's cognitive development in dual-earner families with a shift worker, it is important to check whether fathers' average engagement varies depending on parents' work schedules. If fathers were consistently more (or less) engaged with their children in families with a shift worker than in other dual-earner families, and if children's development also varied by parents' employment schedules, then a mediation model might be more appropriate than the interactive model proposed in the present study.

However, Table 2 demonstrates that there is no statistically significant variation in fathers' positive engagement in dual-earner families on the basis of parents' work schedules at the baseline observation. This echoes past findings (Weinshenker, 2016; Wight et al., 2008). For comparative purposes, Table 2 also reports average mother/family engagement for each work schedule category. Here there is greater variation. Specifically, mothers who work an 'other' type of schedule, such as a rotating or variable shift, and whose partners work during the day, report greater engagement than mothers in couples who both work during the day, as well as more than couples in which one parent has a fixed evening or night shift while the other works during the day. 


\section{Multivariate Results}

Cognitive development in 24-month-olds.

Table 3 presents the most relevant regression coefficients from a set of models predicting children's cognitive scores at 24 months. Full results are available in the online supplement, Table A1. Model 1 includes only the predictors displayed in the table. With no additional controls, either parent's fixed evening or night shift is associated with lower cognitive scores, compared to couples in which both parents work during the day. At the same time, both father engagement and mother/family engagement are predicted to enhance children's cognitive development, which is consistent with a voluminous literature.

The column for Model 2 shows what happens when the additional controls in Table 1, along with a prior measure of the child's cognitive development, are added to the regression. Specifically, mother/family engagement no longer predicts children's cognitive growth when father engagement, the child's prior development, and a variety of socioeconomic and demographic factors are controlled. Conversely, father engagement continues to have a positive effect on children's later cognitive development, even in the presence of all the controls. In a similar way, parental evening and night work retain their negative effects on the outcome.

The results for Model 3 address the main question posed by this study: can positive father engagement ameliorate the harmful effects of shift work? The answer is partially affirmative and partially negative. There is one significant and positive interaction effect, between father engagement and the situation when the mother works an evening or night shift. This suggests that father engagement can counteract the negative effect of maternal shift work when the father is responsible for the young child in the evening or at night. If the father is the one with the nonstandard schedule, however, there is no significant interaction. 
Finally, Model 4 adds concurrent measures of engagement and of parental work schedules to the model. In the presence of these concurrent measures, there is no substantial change in the coefficients for the five interaction terms that are this study's central concerns. Father engagement is still predicted to have a heightened effect on children's subsequent cognitive growth when the father works during the day and the mother works an evening or night shift. The inclusion of concurrent control variables in Model 4 provides greater confidence that the significant interaction represents a true longitudinal effect of prior work shifts and engagement on children's subsequent abilities.

\section{Cognitive development in four-year-olds.}

Table 4 presents results analogous to those in Table 3, except that now children's cognitive scores at age four are regressed on predictors measured two years earlier. (Full model results are in Table A2 in the online supplement.) Because the Early Reading and Math Assessment Battery is measured on a different scale than the BSF-R, the sizes of the coefficient are much smaller. However, Model 1 resembles the previous findings in several respects. Once again, father and mother/family engagement are predicted to increase children's cognitive scores. Also similar to Table 3, either parent's evening or night work is associated with lower scores.

Once additional controls are added, however, the findings about four-year-olds diverge from those for 24-month-olds. The coefficients reported for Model 2 shows that the added controls statistically explain all the effects of parents' engagement, as well as all the negative effects of shift work that were seen in Model 1. At the same time, there is one new finding of significance. When the father works during the day and the mother has a rotating or other nonstandard shift, children's cognitive scores are predicted to be higher than in families in which both parents have day shifts. Even though mother/family engagement is controlled, this result 
may reflect the finding in Table 2 that mother engagement tends to be high in this particular dual-earner work schedule.

Turning to Model 3, there are no significant interactions between engagement and shift work. In other words, the central hypothesis of the study is not supported in this set of results. This remains true when concurrent measures are controlled (Model 4). However, it must be kept in mind that there is a larger gap between the measurement of the predictors and of the outcome than in the previous results (24 months as opposed to 15). It is possible that significant effects would be found in data collected during a shorter time frame.

Results by usage of non-parental caregivers.

It was hypothesized that the effect of father engagement would be moderated by the use of nonparental child care. Specifically, I expected father engagement to counteract the effect of shift work more for children who have no non-parental caregivers; that is, the parents rely only on themselves to care for their child. It was also expected to matter more when the child has a nonparental caregiver and the mother, but not the father, has non-standard employment hours. In this situation, the father is likely to be the child's caregiver in the evening or at night.

To test these hypotheses, the sample was split into two groups: the roughly $25 \%$ of families who have no non-parental care for the target child, and the remainder who do use such care. To assess the possibility that differences between these groups of families are caused by selection into usage of non-parental care, the average characteristics of the sub-samples were compared; the results are shown in supplemental Table A4. In many ways, dual-earner families do not differ depending on whether the child has non-parental caregivers. There are no significant differences at the baseline observation in children's cognitive scores, the amount of 
father engagement, fathers' hours of work, family receipt of government income support, father or child age, child gender, parents' marital status, or child's special needs or birth weight.

On the other hand, parents with no other caregivers for their young children are much more likely to have work schedules in which either the mother's employment is limited, or the two parents' hours do not overlap. In 67 percent of families who have no outside caregiver for their nine-month-old, the mother works part-time; the same is true of only 34 percent of families with an outside caregiver. The corresponding percentages for two-year-olds are very similar. In addition, only 30 percent of parents of nine-month-olds who have no outside caregiver both work during the day. (In the bulk of these families, the mother works part-time.) The corresponding percentage is still low (35 percent) when children are two years old. This indicates that parents with no non-parental caregiver tend to have more traditional gender divisions of income-earning and caregiving responsibilities, particularly if both parents work during the day.

There are also a few other small, but statistically significant differences based on the usage of outside care. At both observations, parents who rely on no other caregivers have a greater average number of children. At nine months, the father is more likely to be white. In addition, at the two-year-old observation, mothers in these families report more engagement, families are unlikely to be in the highest quintile of socioeconomic status, children's homes tend to have many books, and children tend to watch little television. Although the large number of controls in the statistical models should adjust for any differences, the distinctive nature of the sub-samples should be kept in mind.

The regression results for subgroups defined by usage of outside child care are displayed in Table 5 and in Table A3 in the online supplement. Results for models predicting BSF-R scores at age two are on the left. Recall that in Table 3, there was a positive interaction between father 
engagement and the mother's evening or night shift, meaning that engagement reduced the negative impact of this employment schedule. The results in Table 5 reveal that this effect obtains only if the child spends time with an outside caregiver. When the parents use no outside care, there are no interactions between their employment schedules and the level of father engagement.

The models on the right side of Table 5 show the results of the same analysis when predictors measured when the child is two years old are regressed upon Early Reading and Math Assessment scores at age 4. For the entire sample, there were no significant interactions between father engagement and shift work. However, among the sub-sample of children who spend time in non-parental care, there is an effect. Specifically, father engagement ameliorates the negative effect on children when both parents are shift workers. As in the left side of the table, there are no significant interactions between parents' schedules and father engagement if the child is only cared for by the parents.

\section{Discussion}

The question posed in this study is whether men's positive engagement with their young children can counteract the negative effects of nonstandard employment hours on young children's cognitive development in dual-earner families. This proves to be the case in several instances. First, positive engagement with nine-month-olds ameliorates the negative impact of maternal evening and night work, particularly when the child is regularly cared for a by a third party. Non-parental care is most readily available during daytime hours, and the combination of outside care during the day and maternal shift work at night presumably increases the relative amount of time the child spends with the father, compared with the mother. In turn, this magnifies the importance of the quality of parenting the father provides. 
There are no significant interaction effects between 24-month engagement and shift work in predicting four-year-olds' cognitive development in the entire sample. On the other hand, father engagement leads to better cognitive outcomes in four-year-olds when both parents are shift workers two years earlier if the child spends time in non-parental care. What might these results signify? Here I offer two conjectures. First, it has been noted that usage of non-parental care has a strong positive association with mothers' hours, but not fathers' (see Table A3 in the supplement). Therefore, this result may be explicable with the same logic as above. To the extent that the use of non-parental care is a proxy for maternal hours, the child tends to spend relatively more time with the father than the mother, rendering his engagement more consequential. Second, it may be that something about the combination of two shift workers, both subject to consequences such as fatigue (Li et al., 2014), makes father engagement especially valuable all by itself.

In drawing conclusions from this study, several limitations must be kept in mind. First, it must be emphasized that this study examined a subset of families with opposite-sex, biological or adoptive, dual-earner parents who remained together over two observations spaced 15 to 24 months apart. The findings might be different among families with a nonresident father, single earner families, same-sex couples, or in unstable family situations. These are important avenues for future research.

Second, although conclusions about causation are strengthened by longitudinal analysis and a rich set of control measures, possibilities such as spurious correlation and selection cannot be conclusively ruled out. Third, although the ECLS-B provides well-validated, multidimensional measures of children's cognitive abilities, the other measures in the study are based on stylized survey questions. As such, not only are they subject to self-report bias, but the 
respondents were also constrained to use the forced-choice answers that they were offered. Related to this, the measures of positive engagement are measures of the frequency with which parents report interacting with their children in specific ways. They do not measure the quality of such engagement, so the results do not distinguish whether father engagement is ageappropriate, stimulating, and positive in other ways. Although the ECLS-B researchers assessed the quality of interaction between children and their primary parents on the basis of in-home observation, there was no corresponding assessment for the second parent; therefore, quality of interaction was not included in this study.

Finally, it is important to note that the ECLS-B offered no information about parental work schedules in between interviews. As such, it is not possible to test the effect of the duration of time parents work non-standard shifts, as many studies have done (e.g., Han, 2008; Han \& Fox, 2011).

In spite of these limitations, this study has provided valuable evidence that fathers can promote development among children faced with the risk factor of parental shift work. Although previous research has indicated that men's positive engagement with their children does not necessarily increase when parents have non-overlapping employment hours (Weinshenker, 2016; Wight et al., 2008), it would be a mistake for this to be the sole take-away message. There is considerable variation in how engaged fathers of young children are in this situation, and when such fathers do play with their children, read to them, and so on, it can promote children's cognitive growth more strongly than in other situations.

In the future, researchers should seek to confirm the findings of this study and extend them to other types of families, including families where the child's primary male parent is a social rather than a biological father. Particularly if they can be replicated, the conclusion of the 
present study is relevant not only to researchers, but also to the large number of couples who are employed at non-overlapping hours. Regardless of whether they chose differing schedules on purpose or found themselves constrained to accept such employment schedules, couples should be aware that father engagement can be even more valuable in their situation than in others.

In addition, professionals who support fathers and families, including the leaders of Responsible Fatherhood programs for low-income men (Roy \& Dyson, 2010), should help spread the word when working with parents who hold or are considering non-standard employment. In spite of the increasing value placed on paternal engagement in U.S. culture, income provision remains inextricably linked to successful fatherhood (Townsend, 2002). If fathers in off-scheduled couples can be encouraged to see their situations as a unique opportunity to fulfil both the income-earner and the engaged parent roles, their children stand to be the beneficiaries.

\section{References}

Alterman, T., Luckhaupt, S. E., Dahlhamer, J. M., Ward, B. W., \& Calvert, G. M. (2013). Prevalence Rates of Work Organization Characteristics Among Workers in the U.S.: Data From the 2010 National Health Interview Survey. American Journal of Industrial Medicine, 56, 647-659. doi: 10.1002/ajim.22108

Baker, C. E. (2016). African American and Hispanic Fathers' Work Characteristics and Preschool Children's Cognitive Development. Journal of Family Issues, 37, 1514-1534 Bellavia, G., \& Frone, M. R. (2004). Work-family Conflict. In J. Barling, E. K. Kelloway \& M. R. Frone (Eds.), Handbook of Work Stress (pp. 113-148). Thousand Oaks, CA: Russell Sage. 
Bronfenbrenner, U. (1994). Ecological Models of Human Development. In T. Husen \& T. N. Postlethwaite (Eds.), International Encyclopedia of Education (2nd ed., Vol. 3, pp. 16431647). Oxford, UK: Pergamon Press.

Clawson, D., \& Gerstel, N. (2014). Unequal Time: Gender, Class, and Family in Employment Schedules. New York: Russell Sage Foundation.

Coverman, S. (1983). Gender, Domestic Labor Time, and Wage Inequality. American Sociological Review, 48, 623-637

Daniel, S. S., Grzywacz, J. G., Leerkes, E., Tucker, J., \& Han, W.-J. (2009). Nonstandard maternal work schedules during infancy: Implications for children's early behavior problems. Infant Behavior and Development, 32, 195-207

Davis, K. D., Crouter, A. C., \& McHale, S. M. (2006). Implications of Shift Work for ParentAdolescent Relationships in Dual-earner Families. Family Relations, 55, 450-460

Davis, K. D., Goodman, W. B., Pirretti, A. E., \& Almeida, D. M. (2008). Nonstandard Work Schedules, Perceived Family Well-Being, and Daily Stressors. Journal of Marriage and Family, 70, 991-1003. doi: 10.1111/j.1741-3737.2008.00541.x

Dunifon, R., Kalil, A., \& Bajracharya, A. (2005). Maternal Working Conditions and Child Wellbeing in Welfare-leaving Families. Developmental Psychology, 41, 851-859

Duursma, E. (2014). The Effects of Fathers' and Mothers' Reading to Their Children on Language Outcomes of Children Participating in Early Head Start in the United States. Fathering, 12, 283-302. doi: 10.3149/fth.1203.283

Grzywacz, J. G., Daniel, S. S., Tucker, J., Walls, J., \& Leerkes, E. (2011). Nonstandard Work Schedules and Developmentally Generative Parenting Practices: An Application of Propensity Score Techniques. Family Relations, 60, 45-59 
Han, W.-J. (2005). Maternal Nonstandard Work Schedules and Child Cognitive Outcomes. Child Development, 76, 137-154. doi: 10.1111/j.1467-8624.2005.00835.x

Han, W.-J. (2008). Shift Work and Child Behavioral Outcomes. Work, Employment, and Society, $22,67-87$

Han, W.-J., \& Fox, L. E. (2011). Parental Work Schedules and Children’s Cognitive Trajectories. Journal of Marriage and Family, 73, 962-980. doi: 10.1111/j.17413737.2011.00862.x

Han, W.-j., \& Miller, D. P. (2009). Parental Work Schedules and Adolescent Depression. Health Sociology Review, 18, 36-49

Heyman, J. (2000). The Widening Gap: Why America's Working Families Are in Jeopardy and What Can Be Done About It. New York: Basic Books.

Johnson, D. (2005). Two-Wave Panel Analysis: Comparing Statistical Methods for Studying the Effects of Transitions. Journal of Marriage and Family, 67, 1061-1075. doi:

10.1111/j.1741-3737.2005.00194.x

Joshi, P., \& Bogen, K. (2007). Nonstandard Schedules and Young Children's Behavioral Outcomes Among Working Low-Income Families. Journal of Marriage and Family, 69, 139-156. doi: 10.1111/j.1741-3737.2006.00350.x

Kalil, A., Dunifon, R., Crosby, D., \& Su, J. H. (2014). Work Hours, Schedules, and Insufficient Sleep Among Mothers and Their Young Children. Journal of Marriage and Family, 76, 891-904. doi: 10.1111/jomf.12142

Kalil, A., Ziol-Guest, K. M., \& Epstein, J. L. (2010). Nonstandard Work and Marital Instability: Evidence from the National Longitudinal Survey of Youth. Journal of Marriage and Family, 72, 1289-1300. doi: 10.1111/j.1741-3737.2010.00765.x 
Li, J., Johnson, S. E., Han, W.-J., Andrews, S., Kendall, G., Strazdins, L., \& Dockery, A. (2014). Parents' Nonstandard Work Schedules and Child Well-Being: A Critical Review of the Literature. Journal of Primary Prevention 35, 53-73. doi: 10.1007/s10935-013-0318-z

Lleras, C. (2008). Employment, work conditions, and the home environment in single mother families. Journal of Family Issues, 29, 1268-1297

Martin, A., Ryan, R. M., \& Brooks-Gunn, J. (2007). The joint influence of mother and father parenting on child cognitive outcomes at age 5. Early Childhood Research Quarterly 22, 423-439. doi: 10.1016/j.ecresq.2007.07.001

Nord, C., Edwards, B., Andreassen, C., Green, J. L., Wallner-Allen, K., \& Mulligan, G. (2006). Early Childhood Longitudinal Study, Birth Cohort (ECLS-B): User's Manual for the ECLS-B Longitudinal 9-Month-2-Year Data File and Electronic Codebook. Washington, DC: National Center for Education Statistics, Institute of Education Sciences, U.S. Department of Education.

Nord, C., Edwards, B., Hilpert, R., Branden, L., Andreassen, C., Elmore, A., . . West, J. (2004). Early Childhood Longitudinal Study, Birth Cohort (ECLS-B): User's Manual for the ECLS-B Nine-Month Restricted-Use Data File and Electronic Code Book. Washington, DC: National Center for Education Statistics, Institute of Education Sciences, U.S. Department of Education.

Odom, E. C., Vernon-Feagans, L., \& Crouter, A. C. (2013). Nonstandard maternal work schedules: Implications for African American children's early language outcomes. Early Childhood Research Quarterly, 28, 379-387. doi: 10.1016/j.ecresq.2012.10.001 
Perry-Jenkins, M., Goldberg, A. E., Pierce, C. P., \& Sayer, A. G. (2007). Shift Work, Role Overload, and the Transition to Parenthood. Journal of Marriage and Family, 69, 123138. doi: 10.1111/j.1741-3737.2006.00349.x

Pleck, J. H. (2010). Paternal Involvement: Revised Conceptualization and Theoretical Linkages with Child Outcomes. In M. E. Lamb (Ed.), The Role of the Father in Child Development (5th ed., pp. 58-85). Hoboken, NJ: John Wiley \& Sons.

Presser, H. B. (2003). Working in a 24/7 Economy: Challenges for America's Families. New York: Russell Sage.

Rapoport, B., \& Le Bourdais, C. (2008). Parental Time and Working Schedules. Journal of Population Economics(21), 903-932. doi: 10.1007/s00148-007-0147-6

Rosenbaum, E., \& Morett, C. R. (2009). The Effect of Parents' Joint Work Schedules on Infants' Behavior Over the First Two Years of Life: Evidence from the ECLSB. Maternal and Child Health Journal, 13, 732-744

Ross Phillips, K. (2002). Parent Work and Child Well-being in Low-income Families. Washington, DC: Urban Institute.

Roy, K. M., \& Dyson, O. (2010). Making Daddies into Fathers: Community-based Fatherhood Programs and the Construction of Masculinities for Low-income African American Men. American Journal of Community Psychology, 45, 139-154

Royston, P. (2004). Multiple Imputation of Missing Values. Stata Journal, 4, 227-241

Snow, K., Thalji, L., Derecho, A., Wheeless, S., Lennon, J., Kinsey, S., . . Park, J. (2007). Early Childhood Longitudinal Study, Birth Cohort (ECLS-B): Preschool Year Data File User's Manual (2005-06). Washington, DC: National Center for Education Statistics, Institute of Education Sciences, U.S. Department of Education. 
Strazdins, L., Clements, M. S., Korda, R. J., Broom, D. H., \& D'Souza, R. M. (2006). Unsociable Work? Nonstandard Work Schedules, Family Relationships, and Children's Well-Being. Journal of Marriage and Family, 68, 394-410. doi: 10.1111/j.1741-3737.2006.00260.x

Tamis-LeMonda, C. S., Baumwell, L., \& Cabrera, N. J. (2013). Fathers' Role in Children's Language Development. In N. J. Cabrera \& C. S. Tamis-LeMonda (Eds.), Handbook of Father Involvement: Multidisciplinary Perspectives (2nd ed., pp. 135-158). New York: Routledge.

Tammelin, M., Malinen, K., Rönkä, A., \& Verhoef, M. (2017). Work Schedules and WorkFamily Conflict Among Dual Earners in Finland, the Netherlands, and the United Kingdom. Journal of Family Issues, 38, 3-24

Townsend, N. W. (2002). The Package Deal: Marriage, Work, and Fatherhood in Men's Lives. Philadelphia: Temple University Press.

Weinshenker, M. (2016). Nonstandard Parental Employment Schedules and Father Involvement. Community, Work, \& Family, 19, 396-413. doi: 10.1080/13668803.2015.1074544

Wight, V. R., Raley, S. B., \& Bianchi, S. M. (2008). Time for Children, One's Spouse and Oneself among Parents Who Work Nonstandard Hours. Social Forces, 87, 243-271. doi: 10.1353/sof.0.0092 
Table 1. Weighted Means or Proportions for Predictor Variables

\begin{tabular}{|c|c|c|}
\hline Variables & 9 month & 24 month \\
\hline \multicolumn{3}{|l|}{ Prior employment schedule } \\
\hline Both day & .60 & .61 \\
\hline Mother evening/night + father day & .09 & .10 \\
\hline Mother day + father evening/night & .08 & .07 \\
\hline Mother other + father day & .10 & .08 \\
\hline Mother day + father other & .07 & .08 \\
\hline Both nonstandard & .07 & .05 \\
\hline Prior father engagement & 4.33 & 4.13 \\
\hline Prior mother/family engagement & 4.60 & 4.62 \\
\hline Prior cognitive score ${ }^{\mathrm{a}}$ & 76.86 & 129.33 \\
\hline \multicolumn{3}{|l|}{ SES quartile } \\
\hline Lowest & .06 & .05 \\
\hline $2^{\text {nd }}$ & .15 & .15 \\
\hline $3^{\text {rd }}$ & .22 & .22 \\
\hline $4^{\text {th }}$ & .28 & .28 \\
\hline Highest & .28 & .30 \\
\hline Mother employed $<35$ hours & .42 & .41 \\
\hline Mother employed $>45$ hours & .08 & .09 \\
\hline Father employed $<35$ hours & .06 & .06 \\
\hline Father employed $>45$ hours & .35 & .35 \\
\hline Receipt of government support & .19 & .13 \\
\hline Father age (years) & 32.13 & 33.71 \\
\hline \multicolumn{3}{|l|}{ Father race } \\
\hline Non-Hispanic white & .69 & .72 \\
\hline Non-Hispanic black & .08 & .06 \\
\hline Hispanic & .19 & .17 \\
\hline Asian/Pacific Islander & .03 & .03 \\
\hline Other & .02 & .02 \\
\hline
\end{tabular}


Table 1, cont.

\begin{tabular}{|c|c|c|}
\hline Variables & $\begin{array}{l}9 \text { month } \\
\mathrm{N}=2,450\end{array}$ & $\begin{array}{l}24 \text { month } \\
\mathrm{N}=2,200\end{array}$ \\
\hline Married & .87 & .91 \\
\hline Number of other children in household & 0.89 & 1.00 \\
\hline \multicolumn{3}{|l|}{ Hours in non-parental care } \\
\hline None & .24 & .25 \\
\hline Low $(1-40)$ & .60 & .60 \\
\hline High $(41+)$ & .16 & .15 \\
\hline \multicolumn{3}{|l|}{ Type of non-parental care } \\
\hline None & .24 & .25 \\
\hline Center & .13 & .23 \\
\hline Informal & .63 & .52 \\
\hline Child age (months) & 10.37 & 24.28 \\
\hline Child female & .48 & .48 \\
\hline Child has special needs & .06 & .10 \\
\hline Child low birth weight & .06 & .06 \\
\hline Literacy environment & - & 0.27 \\
\hline Weekday hours child watches TV/movies & - & 2.49 \\
\hline \multicolumn{3}{|l|}{ Concurrent employment (vs. both day) } \\
\hline Both day & .52 & .50 \\
\hline Mother evening/night + father day & .07 & .06 \\
\hline Mother day + father evening/night & .06 & .95 \\
\hline Mother other + father day & .06 & .08 \\
\hline Mother day + father other & .06 & .06 \\
\hline Both nonstandard & .04 & .04 \\
\hline Sole-earner father & .16 & .16 \\
\hline Sole-earner mother & .03 & .03 \\
\hline No earners & .00 & .01 \\
\hline Concurrent father engagement & 4.12 & 3.64 \\
\hline Concurrent mother/family engagement & 4.63 & 4.25 \\
\hline
\end{tabular}

a month BSF-R mental scale score is used to predict 24 month BSF-R mental scale score; 24 month BSF-R mental scale score is used to predict age 4 Early Reading and Math Assessment score 
Table 2. Crosstabulation of Parental Engagement and Joint Employment Schedule

Panel A: 9 month $(\mathrm{N}=2,450)$

\begin{tabular}{lcc}
\hline & Father engagement & $\begin{array}{c}\text { Mother/family } \\
\text { engagement }\end{array}$ \\
& & \\
\hline Joint employment schedule & 4.31 & 4.58 \\
Both day & 4.39 & 4.57 \\
Mother evening/night + father day & 4.41 & 4.49 \\
Mother day + father evening/night & 4.31 & $4.77^{\mathrm{abc}}$ \\
Mother other + father day & 4.30 & 4.58 \\
Mother day + father other & 4.39 & 4.65 \\
Both nonstandard &
\end{tabular}

Panel B: 24 month $(\mathrm{N}=2,200)$

Father engagement Mother/family

engagement

Joint employment schedule

Both day

Mother evening/night + father day

Mother day + father evening/night

Mother other + father day

Mother day + father other

Both nonstandard
4.13

4.14

4.14

4.15

4.10

4.18
4.63

$4.86^{\mathrm{abc}}$

4.58

4.54

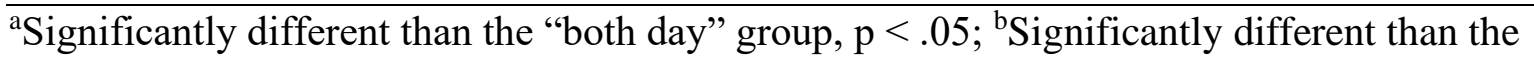
"mother evening/night + father day" group, $p<.05$; 'Significantly different than the "mother day + father evening/night group, $\mathrm{p}<.05$ 
Table 3. Selected Coefficients for Model Predicting BSF-R Mental Scale Scores at 24 Months

\begin{tabular}{|c|c|c|c|c|}
\hline Variables & $\begin{array}{l}\text { Model 1: work } \\
\text { schedule }+ \\
\text { engagement } \\
\mathrm{N}=2,450\end{array}$ & $\begin{array}{l}\text { Model 2: }(1)+ \\
\text { controls } \\
N=2,450\end{array}$ & $\begin{array}{l}\text { Model 3: }(2)+ \\
\text { interactions } \\
N=2,450\end{array}$ & $\begin{array}{l}\text { Model 4: }(3)+ \\
\text { concurrent } \\
\text { predictors } \\
\mathrm{N}=2,450\end{array}$ \\
\hline \multicolumn{5}{|l|}{ Prior employment schedule (vs. both day) } \\
\hline Mother evening/night + father day & $-2.92 *$ & $-2.25 * *$ & $-12.65 * *$ & $-11.03 * *$ \\
\hline Mother day + father evening/night & $-4.60 * * *$ & $-2.89 * *$ & -4.69 & -4.02 \\
\hline Mother other + father day & -0.76 & -0.92 & -6.36 & -4.58 \\
\hline Mother day + father other & -0.45 & -0.15 & -1.98 & -1.02 \\
\hline Both nonstandard & -1.97 & -1.53 & -8.57 & -8.03 \\
\hline Prior father engagement & $0.93 *$ & $0.64 *$ & 0.16 & -0.72 \\
\hline Prior mother/family engagement & $2.01 * * *$ & 0.27 & 0.30 & -0.43 \\
\hline Father engagement $*(\mathrm{M}$ eve/nite $+\mathrm{F}$ day $)$ & & & $2.36^{* *}$ & $2.17 *$ \\
\hline Father engagement $*(\mathrm{M}$ day $+\mathrm{F}$ eve/nite $)$ & & & 0.41 & 0.27 \\
\hline Father engagement $*(\mathrm{M}$ eve/nite $+\mathrm{F}$ day $)$ & & & 1.24 & 0.92 \\
\hline Father engagement $*(\mathrm{M}$ day $+\mathrm{F}$ eve/nite $)$ & & & 0.42 & 0.14 \\
\hline Father engagement $*$ (both nonstandard) & & & 1.60 & 1.43 \\
\hline
\end{tabular}

$* p<.05 ; * * p<.01 ; * * * p<.001$ 
Table 4. Selected Coefficients for Model Predicting Early Reading and Math Assessment Scores at 4 Years

\begin{tabular}{|c|c|c|c|c|}
\hline Variables & $\begin{array}{l}\text { Model 1: work } \\
\text { schedule }+ \\
\text { engagement } \\
\mathrm{N}=2,200\end{array}$ & $\begin{array}{l}\text { Model 2: }(1)+ \\
\text { controls } \\
\mathrm{N}=2,200\end{array}$ & $\begin{array}{l}\text { Model 3: }(2)+ \\
\text { interactions } \\
\mathrm{N}=2,200\end{array}$ & $\begin{array}{l}\text { Model 4: }(3)+ \\
\text { concurrent } \\
\text { predictors } \\
\mathrm{N}=2,200\end{array}$ \\
\hline \multicolumn{5}{|l|}{ Prior employment schedule (vs. both day) } \\
\hline Mother evening/night + father day & $-0.41 *$ & -0.12 & 0.46 & 0.53 \\
\hline Mother day + father evening/night & $-0.41 *$ & -0.04 & 1.05 & 1.15 \\
\hline Mother other + father day & 0.27 & $0.20 *$ & $0.99 *$ & $1.05 *$ \\
\hline Mother day + father other & 0.05 & 0.16 & -0.14 & 0.03 \\
\hline Both nonstandard & -0.35 & 0.06 & -0.95 & -0.83 \\
\hline Prior father engagement & $0.14 *$ & 0.03 & 0.05 & 0.03 \\
\hline Prior mother/family engagement & $0.20 * *$ & 0.03 & 0.00 & -0.02 \\
\hline Father engagement $*(\mathrm{M}$ eve/nite $+\mathrm{F}$ day $)$ & & & -0.14 & -0.14 \\
\hline Father engagement $*(\mathrm{M}$ day $+\mathrm{F}$ eve/nite $)$ & & & -0.26 & -0.26 \\
\hline Father engagement $*(\mathrm{M}$ eve/nite $+\mathrm{F}$ day $)$ & & & -0.19 & -0.20 \\
\hline Father engagement $*(\mathrm{M}$ day $+\mathrm{F}$ eve/nite $)$ & & & 0.07 & 0.06 \\
\hline Father engagement $*$ (both nonstandard) & & & 0.24 & 0.23 \\
\hline
\end{tabular}

$* p<.05 ; * * p<.01 ; * * * p<.001$ 
Table 5. Selected Coefficients for Models Predicting Children's Cognitive Scores, by Usage of Non-parental Care

BSF-R Mental Scale Scores at 24 Months Early Reading and Math Assessment

Scores at 4 Years

\begin{tabular}{|c|c|c|c|c|}
\hline Variables & $\begin{array}{l}\text { Non-parental care } \\
\mathrm{N}=1,900\end{array}$ & $\begin{array}{l}\text { No non-parental } \\
\text { care } \\
\mathrm{N}=550\end{array}$ & $\begin{array}{l}\text { Non-parental care } \\
\mathrm{N}=1,650\end{array}$ & $\begin{array}{l}\text { No non-parental } \\
\text { care } \\
\mathrm{N}=550\end{array}$ \\
\hline \multicolumn{5}{|l|}{ Prior employment schedule (vs. both day) } \\
\hline Mother evening/night + father day & $-19.98 *$ & 0.46 & 0.02 & 1.63 \\
\hline Mother day + father evening/night & -0.42 & -5.55 & 0.12 & 2.23 \\
\hline Mother other + father day & -2.00 & -5.94 & 1.06 & 0.95 \\
\hline Mother day + father other & -1.18 & -2.44 & 0.10 & 0.13 \\
\hline Both nonstandard & -19.00 & 9.79 & $-2.13^{*}$ & 1.32 \\
\hline Prior father engagement & -0.92 & 0.11 & 0.07 & -0.02 \\
\hline Prior mother/family engagement & -0.45 & -0.87 & -0.11 & 0.12 \\
\hline Father engagement $*(\mathrm{M}$ eve/nite $+\mathrm{F}$ day $)$ & $4.19 *$ & -0.68 & 0.00 & -0.40 \\
\hline Father engagement $*(\mathrm{M}$ day $+\mathrm{F}$ eve/nite $)$ & -0.61 & 0.35 & -0.06 & -0.47 \\
\hline Father engagement $*(\mathrm{M}$ eve/nite $+\mathrm{F}$ day $)$ & 0.35 & 1.22 & -0.19 & -0.19 \\
\hline Father engagement $*(\mathrm{M}$ day $+\mathrm{F}$ eve/nite $)$ & 0.36 & -0.56 & 0.01 & 0.09 \\
\hline Father engagement $*$ (both nonstandard) & 3.67 & -2.39 & $0.54 *$ & -0.29 \\
\hline
\end{tabular}

$* p<.05 ; * * p<.01 ; * * * p<.001$ 
Table A1. Coefficients for Model Predicting BSF-R Mental Scale Scores at 24 Months

\begin{tabular}{|c|c|c|c|c|}
\hline Variables & $\begin{array}{l}\text { Model 1: } \\
\text { work } \\
\text { schedule + } \\
\text { engage- } \\
\text { ment } \\
\mathrm{N}=2,450\end{array}$ & $\begin{array}{c}\text { Model 2: } \\
(1)+ \\
\text { controls } \\
\mathrm{N}=2,450\end{array}$ & $\begin{array}{l}\text { Model 3: } \\
\text { (2) + inter- } \\
\text { actions } \\
\mathrm{N}=2,450\end{array}$ & $\begin{array}{l}\text { Model 4: } \\
(3)+ \\
\text { concurrent } \\
\text { predictors } \\
\mathrm{N}=2,450\end{array}$ \\
\hline \multicolumn{5}{|l|}{ Prior employment schedule (vs. both day) } \\
\hline Mother evening/night + father day & $-2.92 *$ & $-2.25 * *$ & $-12.65 * *$ & $-11.03 * *$ \\
\hline Mother day + father evening/night & $-4.60 * * *$ & $-2.89 * *$ & -4.69 & -4.02 \\
\hline Mother other + father day & -0.76 & -0.92 & -6.36 & -4.58 \\
\hline Mother day + father other & -0.45 & -0.15 & -1.98 & -1.02 \\
\hline Both nonstandard & -1.97 & -1.53 & -8.57 & -8.03 \\
\hline Prior father engagement & $0.93 *$ & $0.64 *$ & 0.16 & -0.72 \\
\hline Prior mother/family engagement & $2.01 * * *$ & 0.27 & 0.30 & -0.43 \\
\hline 9 month BSF-R mental scale score & & $0.42 * * *$ & $0.42 * * *$ & $0.42 * * *$ \\
\hline \multicolumn{5}{|l|}{ SES quartile (vs. lowest) } \\
\hline $2^{\text {nd }}$ & & -0.03 & 0.05 & 0.09 \\
\hline $3^{\text {rd }}$ & & 0.73 & 0.77 & 0.86 \\
\hline $4^{\text {th }}$ & & $2.88 * *$ & $2.95^{* *}$ & $2.87 * *$ \\
\hline Highest & & $3.86 * * *$ & $3.88 * * *$ & $3.60 * * *$ \\
\hline Mother employed $<35$ hours & & 0.93 & 0.97 & $1.10^{*}$ \\
\hline Mother employed $>45$ hours & & $1.32 *$ & 1.23 & 0.88 \\
\hline Father employed $<35$ hours & & $2.20 * *$ & $2.20 * *$ & $2.31 * *$ \\
\hline Father employed $>45$ hours & & 0.05 & 0.02 & 0.24 \\
\hline Receipt of government support & & $-2.01 * *$ & $-2.09 * *$ & $-2.05^{* *}$ \\
\hline Father age (years) & & -0.05 & -0.05 & -0.04 \\
\hline \multicolumn{5}{|l|}{ Father race (vs. Non-Hispanic white) } \\
\hline Non-Hispanic black & & $-3.11 * * *$ & $-3.08 * * *$ & $-2.66 * * *$ \\
\hline Hispanic & & $-3.93 * * *$ & $-3.96 * * *$ & $-3.60 * * *$ \\
\hline Asian/Pacific Islander & & $-4.86 * * *$ & $-4.81 * * *$ & $-4.31 * * *$ \\
\hline Other & & -0.87 & -0.88 & -0.66 \\
\hline Married & & 0.45 & 0.37 & 0.25 \\
\hline Number of other children in household & & $-0.70 * * *$ & $-0.68 * * *$ & $-0.46^{*}$ \\
\hline
\end{tabular}


Table A1, cont.

\begin{tabular}{|c|c|c|c|c|}
\hline Variables & $\begin{array}{l}\text { Model 1: } \\
\text { work } \\
\text { schedule + } \\
\text { engage- } \\
\text { ment } \\
\mathrm{N}=2,450\end{array}$ & $\begin{array}{l}\text { Model 2: } \\
\quad(1)+ \\
\text { controls } \\
\mathrm{N}=2,450\end{array}$ & $\begin{array}{l}\text { Model 3: } \\
\text { (2) + inter- } \\
\text { actions } \\
\mathrm{N}=2,450\end{array}$ & $\begin{array}{l}\text { Model 4: } \\
\text { (3) }+ \\
\text { concurrent } \\
\text { predictors } \\
\mathrm{N}=2,450\end{array}$ \\
\hline \multicolumn{5}{|l|}{ Hours in non-parental care (vs. none) } \\
\hline Low $(1-40)$ & & 1.41 & 1.31 & 1.29 \\
\hline High $(41+)$ & & 0.99 & 0.94 & 0.92 \\
\hline \multicolumn{5}{|l|}{ Type of non-parental care (vs. none) } \\
\hline Center & & 1.50 & 1.43 & 1.38 \\
\hline Informal & & -1.05 & -1.10 & -1.19 \\
\hline Child age (months) & & $-1.64 * * *$ & $-1.64 * * *$ & $-1.59 * * *$ \\
\hline Child female & & $3.71 * * *$ & $3.67 * * *$ & $3.73 * * *$ \\
\hline Child has special needs & & $-1.76 * *$ & $-1.77 * *$ & $-1.70 * *$ \\
\hline Child low birth weight & & $-1.50 * *$ & $-1.53 * *$ & $-1.88 * * *$ \\
\hline Father engagement $*(\mathrm{M}$ eve/nite $+\mathrm{F}$ day $)$ & & & $2.36 * *$ & $2.17^{*}$ \\
\hline Father engagement $*(\mathrm{M}$ day $+\mathrm{F}$ eve/nite $)$ & & & 0.41 & 0.27 \\
\hline Father engagement $*(\mathrm{M}$ eve/nite $+\mathrm{F}$ day $)$ & & & 1.24 & 0.92 \\
\hline Father engagement $*(\mathrm{M}$ day $+\mathrm{F}$ eve/nite $)$ & & & 0.42 & 0.14 \\
\hline Father engagement $*$ (both nonstandard) & & & 1.60 & 1.43 \\
\hline \multicolumn{5}{|l|}{ Concurrent employment (vs. both day) } \\
\hline Mother evening/night + father day & & & & $-2.10^{*}$ \\
\hline Mother day + father evening/night & & & & 0.47 \\
\hline Mother other + father day & & & & -1.44 \\
\hline Mother day + father other & & & & 0.50 \\
\hline Both nonstandard & & & & 0.04 \\
\hline Sole-earner father & & & & -0.45 \\
\hline Sole-earner mother & & & & 0.21 \\
\hline No earners & & & & $-6.27 *$ \\
\hline Concurrent father engagement & & & & $1.79 * * *$ \\
\hline Concurrent mother/family engagement & & & & $1.35 * * *$ \\
\hline Constant & $116.60 * * *$ & $109.06 * * *$ & $111.19 * * *$ & $103.61 * * *$ \\
\hline Average $\mathrm{R}^{2}$ & .042 & .249 & .252 & .274 \\
\hline
\end{tabular}

$* p<.05 ; * * p<.01 ; * * * p<.001$ 
Table A2. Coefficients for Model Predicting Early Reading and Math Assessment Scores at 4 Years

\begin{tabular}{|c|c|c|c|c|}
\hline Variables & $\begin{array}{l}\text { Model 1: } \\
\text { work } \\
\text { schedule + } \\
\text { engage- } \\
\text { ment } \\
\mathrm{N}=2,200\end{array}$ & $\begin{array}{l}\text { Model 2: } \\
\begin{array}{c}(1)+ \\
\text { controls } \\
\mathrm{N}=2,200\end{array}\end{array}$ & $\begin{array}{l}\text { Model 3: } \\
(2)+\text { inter- } \\
\text { actions } \\
\mathrm{N}=2,200\end{array}$ & $\begin{array}{l}\text { Model 4: } \\
\quad(3)+ \\
\text { concurrent } \\
\text { predictors } \\
\mathrm{N}=2,200\end{array}$ \\
\hline \multicolumn{5}{|l|}{ Prior employment schedule (vs. both day) } \\
\hline Mother evening/night + father day & $-0.41 *$ & -0.12 & 0.46 & 0.53 \\
\hline Mother day + father evening/night & $-0.41^{*}$ & -0.04 & 1.05 & 1.15 \\
\hline Mother other + father day & 0.27 & $0.20 *$ & $0.99 *$ & $1.05^{*}$ \\
\hline Mother day + father other & 0.05 & 0.16 & -0.14 & 0.03 \\
\hline Both nonstandard & -0.35 & 0.06 & -0.95 & -0.83 \\
\hline Prior father engagement & $0.14 *$ & 0.03 & 0.05 & 0.03 \\
\hline Prior mother/family engagement & $0.20 * *$ & 0.03 & 0.00 & -0.02 \\
\hline 24 month BSF-R mental scale score & & $0.04 * * *$ & $0.04 * * *$ & $0.04 * * *$ \\
\hline \multicolumn{5}{|l|}{ SES quartile (vs. lowest) } \\
\hline $2^{\text {nd }}$ & & -0.08 & -0.06 & -0.11 \\
\hline $3^{\text {rd }}$ & & 0.12 & 0.15 & 0.09 \\
\hline $4^{\text {th }}$ & & $0.54 * *$ & $0.55^{* *}$ & $0.49 * *$ \\
\hline Highest & & $0.82^{* * *}$ & $0.83^{* * *}$ & $0.75^{* * *}$ \\
\hline Mother employed $<35$ hours & & 0.11 & 0.12 & $0.13^{*}$ \\
\hline Mother employed $>45$ hours & & 0.07 & 0.08 & 0.08 \\
\hline Father employed <35 hours & & -0.06 & -0.08 & -0.07 \\
\hline Father employed $>45$ hours & & 0.05 & 0.05 & 0.06 \\
\hline Receipt of government support & & -0.16 & -0.15 & -0.15 \\
\hline Father age (years) & & $0.01 * *$ & $0.01 *$ & $0.01 *$ \\
\hline \multicolumn{5}{|l|}{ Father race (vs. Non-Hispanic white) } \\
\hline Non-Hispanic black & & 0.02 & 0.03 & 0.05 \\
\hline Hispanic & & $-0.17 *$ & $-0.16^{*}$ & -0.14 \\
\hline Asian/Pacific Islander & & $0.74 * * *$ & $0.75 * * *$ & $0.78^{* * * *}$ \\
\hline Other & & -0.21 & -0.22 & -0.23 \\
\hline Married & & 0.11 & 0.10 & 0.10 \\
\hline Number of other children in household & & $-0.16^{* * *}$ & $-0.16 * * *$ & $-0.16^{* * *}$ \\
\hline
\end{tabular}


Table A2, cont.

\begin{tabular}{|c|c|c|c|c|}
\hline Variables & $\begin{array}{l}\text { Model 1: } \\
\text { work } \\
\text { schedule + } \\
\text { engageme } \\
\quad \text { nt } \\
\mathrm{N}=2,200\end{array}$ & $\begin{array}{l}\text { Model 2: } \\
\quad(1)+ \\
\text { controls } \\
\mathrm{N}=2,200\end{array}$ & $\begin{array}{l}\text { Model 3: } \\
\quad(2)+ \\
\text { interaction } \\
\quad \mathrm{s} \\
\mathrm{N}=2,200\end{array}$ & $\begin{array}{l}\text { Model 4: } \\
\text { Non- } \\
\text { parental } \\
\text { care } \\
\mathrm{N}=1,650\end{array}$ \\
\hline \multicolumn{5}{|l|}{ Hours in non-parental care (vs. none) } \\
\hline Low $(1-40)$ & & -0.07 & -0.07 & -0.07 \\
\hline High $(41+)$ & & -0.02 & -0.02 & -0.03 \\
\hline \multicolumn{5}{|l|}{ Type of non-parental care (vs. none) } \\
\hline Center & & -0.04 & -0.04 & -0.06 \\
\hline Informal & & -0.04 & -0.05 & -0.05 \\
\hline Child age (months) & & $0.08^{*}$ & $0.09 *$ & $0.09 * *$ \\
\hline Child female & & 0.07 & 0.07 & 0.06 \\
\hline Child has special needs & & 0.11 & 0.11 & 0.10 \\
\hline Child low birth weight & & -0.01 & -0.01 & 0.00 \\
\hline Literacy environment & & -0.03 & -0.03 & -0.03 \\
\hline Weekday hours child watches TV/movies & & -0.01 & -0.01 & -0.01 \\
\hline Father engagement $*(\mathrm{M}$ eve/nite $+\mathrm{F}$ day $)$ & & & -0.14 & -0.14 \\
\hline Father engagement $*(\mathrm{M}$ day $+\mathrm{F}$ eve/nite $)$ & & & -0.26 & -0.26 \\
\hline Father engagement $*(\mathrm{M}$ eve/nite $+\mathrm{F}$ day $)$ & & & -0.19 & -0.20 \\
\hline Father engagement $*(\mathrm{M}$ day $+\mathrm{F}$ eve/nite $)$ & & & 0.07 & 0.06 \\
\hline Father engagement $*$ (both nonstandard) & & & 0.24 & 0.23 \\
\hline \multicolumn{5}{|l|}{ Concurrent employment (vs. both day) } \\
\hline Mother evening/night + father day & & & & -0.24 \\
\hline Mother day + father evening/night & & & & -0.25 \\
\hline Mother other + father day & & & & -0.06 \\
\hline Mother day + father other & & & & $-0.30 * *$ \\
\hline Both nonstandard & & & & $-0.21^{*}$ \\
\hline Sole-earner father & & & & $-0.25 * *$ \\
\hline Sole-earner mother & & & & 0.09 \\
\hline No earners & & & & -0.16 \\
\hline Concurrent father engagement & & & & 0.05 \\
\hline Concurrent mother/family engagement & & & & 0.04 \\
\hline Constant & $16.04 * * *$ & $9.43 * * *$ & $9.30 * * *$ & $9.13 * * *$ \\
\hline Average $\mathrm{R}^{2}$ & .039 & .301 & .304 & .312 \\
\hline
\end{tabular}

$* p<.05 ; * * p<.01 ; * * * p<.001$ 
Table A3. Coefficients for Models Predicting Children's Cognitive Scores, by Usage of Nonparental Care

\begin{tabular}{|c|c|c|c|c|}
\hline \multirow[b]{2}{*}{ Variables } & \multicolumn{2}{|c|}{$\begin{array}{l}\text { BSF-R Mental Scale } \\
\text { Scores at } 24 \text { Months }\end{array}$} & \multicolumn{2}{|c|}{$\begin{array}{l}\text { Early Reading and } \\
\text { Math Assessment } \\
\text { Scores at } 4 \text { Years }\end{array}$} \\
\hline & $\begin{array}{l}\text { Non- } \\
\text { parental } \\
\text { care } \\
\mathrm{N}=1,900\end{array}$ & $\begin{array}{l}\text { No non- } \\
\text { parental } \\
\text { care } \\
\mathrm{N}=550\end{array}$ & $\begin{array}{l}\text { Non- } \\
\text { parental } \\
\text { care } \\
\mathrm{N}=1,650\end{array}$ & $\begin{array}{l}\text { No non- } \\
\text { parental } \\
\text { care } \\
\mathrm{N}=550\end{array}$ \\
\hline \multicolumn{5}{|l|}{ Prior employment schedule (vs. both day) } \\
\hline Mother evening/night + father day & $-19.98 *$ & 0.46 & 0.02 & 1.63 \\
\hline Mother day + father evening/night & -0.42 & -5.55 & 0.12 & 2.23 \\
\hline Mother other + father day & -2.00 & -5.94 & 1.06 & 0.95 \\
\hline Mother day + father other & -1.18 & -2.44 & 0.10 & 0.13 \\
\hline Both nonstandard & -19.00 & 9.79 & $-2.13 *$ & 1.32 \\
\hline Prior father engagement & -0.92 & 0.11 & 0.07 & -0.02 \\
\hline Prior mother/family engagement & -0.45 & -0.87 & -0.11 & 0.12 \\
\hline 9 month BSF-R mental scale score & $0.43 * * *$ & $0.35^{* * *}$ & $0.03 * * *$ & $0.05 * * *$ \\
\hline \multicolumn{5}{|l|}{ SES quartile (vs. lowest) } \\
\hline $2^{\text {nd }}$ & 0.91 & -2.03 & 0.15 & -0.48 \\
\hline $3^{\text {rd }}$ & 1.89 & -2.09 & 0.26 & -0.15 \\
\hline $4^{\text {th }}$ & $4.40 * *$ & -1.97 & $0.75^{*}$ & 0.15 \\
\hline Highest & $4.46^{* *}$ & 0.11 & $1.02 * * *$ & 0.37 \\
\hline Mother employed $<35$ hours & $1.72 *$ & -0.36 & 0.07 & 0.17 \\
\hline Mother employed $>45$ hours & 1.22 & -0.75 & -0.03 & 0.21 \\
\hline Father employed <35 hours & 2.00 & $3.49 *$ & -0.21 & 0.14 \\
\hline Father employed $>45$ hours & 0.46 & -0.02 & 0.09 & -0.04 \\
\hline Receipt of government support & -1.94 & -2.45 & -0.07 & -0.24 \\
\hline Father age (years) & -0.03 & -0.01 & $0.02 *$ & 0.00 \\
\hline \multicolumn{5}{|l|}{ Father race (vs. Non-Hispanic white) } \\
\hline Non-Hispanic black & $-3.03 * *$ & -0.46 & 0.09 & 0.01 \\
\hline Hispanic & $-3.25 * * *$ & $-4.43 * * *$ & -0.16 & -0.19 \\
\hline Asian/Pacific Islander & $-4.05 * * *$ & $-5.18 * * *$ & $0.85^{* * *}$ & $0.66^{* *}$ \\
\hline Other & -0.08 & -1.36 & -0.11 & -0.46 \\
\hline Married & 0.46 & 0.31 & 0.05 & 0.20 \\
\hline Number of other children in household & -0.44 & -0.88 & $-0.18 * * *$ & $-0.17 * *$ \\
\hline
\end{tabular}


Table A3, cont.

\begin{tabular}{|c|c|c|c|c|}
\hline \multirow[b]{2}{*}{ Variables } & \multicolumn{2}{|c|}{$\begin{array}{l}\text { BSF-R Mental Scale } \\
\text { Scores at } 24 \text { Months }\end{array}$} & \multicolumn{2}{|c|}{$\begin{array}{l}\text { Early Reading and } \\
\text { Math Assessment } \\
\text { Scores at } 4 \text { Years }\end{array}$} \\
\hline & $\begin{array}{l}\text { Non- } \\
\text { parental } \\
\text { care } \\
\mathrm{N}=1,900\end{array}$ & $\begin{array}{l}\text { No non- } \\
\text { parental } \\
\text { care } \\
\mathrm{N}=550\end{array}$ & $\begin{array}{l}\text { Non- } \\
\text { parental } \\
\text { care } \\
\mathrm{N}=1,650\end{array}$ & $\begin{array}{l}\text { No non- } \\
\text { parental } \\
\text { care } \\
\mathrm{N}=550\end{array}$ \\
\hline \multicolumn{5}{|l|}{ Hours in non-parental care (vs. none) } \\
\hline \multicolumn{5}{|l|}{ Low $(1-40)$} \\
\hline High $(41+)$ & -0.18 & & 0.00 & \\
\hline \multicolumn{5}{|l|}{ Type of non-parental care (vs. none) } \\
\hline Center & $2.30 * *$ & & 0.00 & \\
\hline \multicolumn{5}{|l|}{ Informal } \\
\hline Child age (months) & $-1.39 * * *$ & $-2.06 * * *$ & $0.13^{*}$ & 0.04 \\
\hline Child female & $3.41 * * *$ & $4.42 * * *$ & 0.11 & 0.01 \\
\hline Child has special needs & -1.47 & -2.48 & 0.10 & 0.18 \\
\hline Child low birth weight & $-2.50 * *$ & -0.89 & -0.12 & 0.23 \\
\hline Literacy environment & & & 0.01 & -0.08 \\
\hline Weekday hours child watches TV/movies & & & 0.00 & -0.03 \\
\hline Father engagement $*(\mathrm{M}$ eve/nite $+\mathrm{F}$ day $)$ & $4.19 *$ & -0.68 & 0.00 & -0.40 \\
\hline Father engagement $*(\mathrm{M}$ day $+\mathrm{F}$ eve/nite $)$ & -0.61 & 0.35 & -0.06 & -0.47 \\
\hline Father engagement $*(\mathrm{M}$ eve/nite $+\mathrm{F}$ day $)$ & 0.35 & 1.22 & -0.19 & -0.19 \\
\hline Father engagement $*(\mathrm{M}$ day $+\mathrm{F}$ eve/nite $)$ & 0.36 & -0.56 & 0.01 & 0.09 \\
\hline Father engagement $*$ (both nonstandard) & 3.67 & -2.39 & $0.54 *$ & -0.29 \\
\hline \multicolumn{5}{|l|}{ Concurrent employment (vs. both day) } \\
\hline Mother evening/night + father day & $-3.02 *$ & -0.18 & -0.36 & -0.13 \\
\hline Mother day + father evening/night & 0.88 & 0.49 & -0.23 & -0.25 \\
\hline Mother other + father day & -0.28 & -2.21 & -0.14 & 0.05 \\
\hline Mother day + father other & -0.03 & 2.49 & -0.21 & $-0.50 *$ \\
\hline Both nonstandard & -0.38 & 0.06 & -0.31 & -0.14 \\
\hline Sole-earner father & -1.06 & 1.64 & -0.18 & $-0.41 *$ \\
\hline Sole-earner mother & 1.38 & -2.14 & 0.04 & 0.33 \\
\hline No earners & $-10.65 * *$ & 3.10 & 0.06 & -0.28 \\
\hline Concurrent father engagement & $1.81 * * *$ & $2.33 * * *$ & 0.01 & 0.06 \\
\hline Concurrent mother/family engagement & $1.64 * * *$ & 0.40 & 0.05 & 0.07 \\
\hline Constant & $99.08 * * *$ & $117.76^{* * * *}$ & $8.68 * * *$ & $9.67 * * *$ \\
\hline Average $\mathrm{R}^{2}$ & .295 & .309 & .324 & .341 \\
\hline
\end{tabular}


Table A4. Summary of Differences between Dual-Earner Couples Based on Usage of Non-parental Care

\begin{tabular}{|c|c|c|c|c|}
\hline \multirow[b]{2}{*}{ Variables } & \multicolumn{2}{|c|}{9 months } & \multicolumn{2}{|c|}{24 months } \\
\hline & $\begin{array}{l}\text { Non-parental } \\
\text { care } \\
\mathrm{N}=1,900\end{array}$ & $\begin{array}{l}\text { No non- } \\
\text { parental care } \\
\mathrm{N}=550\end{array}$ & $\begin{array}{l}\text { Non-parental } \\
\text { care } \\
\mathrm{N}=1,650\end{array}$ & $\begin{array}{l}\text { No non-parental } \\
\text { care } \\
\mathrm{N}=550\end{array}$ \\
\hline Both parents work days & .69 & $.30^{*}$ & .70 & $.35^{*}$ \\
\hline Father engagement & 4.34 & 4.33 & 4.14 & 4.11 \\
\hline Mother/family engagement & 4.58 & 4.67 & 4.59 & $4.73^{*}$ \\
\hline BSF-R mental scale score & 76.95 & 76.57 & 129.72 & 128.18 \\
\hline \multicolumn{5}{|l|}{ SES quartile } \\
\hline Lowest & .06 & .07 & .04 & .06 \\
\hline $2^{\text {nd }}$ & .15 & .18 & .15 & .17 \\
\hline $3^{\text {rd }}$ & .22 & .22 & .20 & .26 \\
\hline $4^{\text {th }}$ & .28 & .28 & .27 & .32 \\
\hline Highest & .29 & .25 & .34 & $.20^{*}$ \\
\hline Mother employed $<35$ hours & .34 & $.67^{*}$ & .33 & $.64 *$ \\
\hline Mother employed $>45$ hours & .09 & .08 & .09 & .09 \\
\hline Father employed <35 hours & .05 & .09 & .05 & .08 \\
\hline Father employed $>45$ hours & .35 & .36 & .37 & .30 \\
\hline Receipt of government support & .18 & .23 & .12 & .14 \\
\hline Father age (years) & 32.10 & 32.22 & 33.77 & 33.53 \\
\hline Father Non-Hispanic white & .67 & $.75^{*}$ & .70 & .76 \\
\hline
\end{tabular}


Table A4, cont.

\begin{tabular}{lcccc}
\hline & \multicolumn{2}{c}{9 months } & \multicolumn{2}{c}{24 months } \\
\hline Variables & $\begin{array}{c}\text { Non-parental } \\
\text { care } \\
\mathrm{N}=1,900\end{array}$ & $\begin{array}{l}\text { No non- } \\
\text { parental care } \\
\mathrm{N}=550\end{array}$ & $\begin{array}{c}\text { Non-parental } \\
\text { care } \\
\mathrm{N}=1,650\end{array}$ & $\begin{array}{l}\text { No non- } \\
\text { parental care } \\
\mathrm{N}=550\end{array}$ \\
\hline Married & .87 & .85 & .91 & .91 \\
Number of other children in household & 0.84 & $1.05^{*}$ & 0.89 & $1.30^{*}$ \\
Child age (months) & 10.36 & 10.40 & 24.32 & 24.17 \\
Child female & .48 & .49 & .47 & .49 \\
Child has special needs & .06 & .07 & .10 & .06 \\
Child low birth weight & .06 & .07 & .06 & .05 \\
Literacy environment & - & - & 21 & $.44 *$ \\
Weekday hours child watches TV/movies & - & - & 2.60 & $2.16^{*}$ \\
\hline
\end{tabular}

${ }^{*}$ Differs from the non-parental care group at $p<.05$ 